\title{
National Survey of the Pharmacokinetics Services at the Ministry of Health Hospitals in Saudi Arabia: Prescribing and Dispensing Medication
}

\author{
Yousef Ahmed Alomi ${ }^{1 * *}$ (D), Rasha Abdelsalam Elshenawy ${ }^{2}$ \\ ${ }^{1}$ The Former General Manager of General Administration of Pharmaceutical Care Head, National Clinical Pharmacy \\ and Pharmacy Practice, the Past Head and Founder, Research Consult and Pharmacy Consult, Ministry of Health, \\ Riyadh, SAUDI ARABIA. \\ ${ }^{2}$ Ministry of Health, Makkah, SAUDI ARABIA.
}

\begin{abstract}
Objectives: To explore the pharmacokinetics services at the Ministry of Health (MOH) hospitals in Saudi Arabia with an emphasis on prescribing and dispensing medication. Methods: This is a 2-month crosssectional national survey of pharmacokinetics services. The study consisted of two parts: the first part captures demographic information and the second part is a questionnaire with 43 questions divided into three domains. The questions are derived from the guidelines of the American Society of HealthSystem Pharmacists (ASHP) and from the literature. We used the 5-point Likert response scale system to obtain responses of the participants; there were close-ended questions. The electronic questionnaire was distributed to all the coordinators of the clinical pharmacy services or to the drug information centers at $\mathrm{MOH}$ hospitals, The data were collected through the Survey Monkey system. Results: A total of 43 hospital pharmacies responded to the survey; the response rate was found to be $86 \%$. The pharmacists and nurses had privileges of prescribing medication as per pharmacokinetics services in nearly 18 (46.15\%) and 16 (41.03\%) hospitals respectively. At 14 (37.84\%) hospitals, pharmacists have the privilege to request an estimation of patient's drug levels and at $12(30.77 \%)$ hospitals, they have the privilege to change drug sampling time. At 15 (38.46\%) hospitals, nurses have the privilege to request an estimation of patient's drug level and at 12 (31.58\%) hospitals, they have the privilege to change drug sampling time. The commonly prescribed medications via pharmacokinetics consultation were gentamicin (23 (71.88\%)), phenytoin (23 (71.88\%)), carbamazepine (22 (70.97\%)), sodium valproate (22 $(70.97 \%))$ and warfarin $(22(70.97 \%))$. The pharmacokinetics altering system during an electronic prescription was found in $9(26.5 \%)$ hospital pharmacies and the pharmacist was found to participate in pharmacokinetics research in $8(23.5 \%)$ hospitals. Conclusion: Healthcare providers including the pharmacists and nurses have a significant role in providing pharmacokinetics services to the patients. Expanding these services with standard guidelines and the electronic prescription is required in order to prevent drug- Pharmacokinetics related problems, improve the clinical outcome of the patient and reduce the economic burden.
\end{abstract}

Key words: Pharmacokinetics, Prescribing, Medication, Dispensing, Ministry of Health, Saudi Arabia.

\section{Received: 03-11-2018;}

Accepted: 25-12-2018

*Correspondence to:

Dr. Yousef Ahmed Alomi

The Former General Manager of General Administration of Pharmaceutical Care Head, National Clinical Pharmacy and Pharmacy Practice, the Past Head and Founder, Research Consult and Pharmacy Consult, Ministry of Health, P.O. Box 100, Riyadh 11392, Riyadh, SAUDI ARABIA.

Phone no: +966 504417712 Email: yalomi@gmail.com

DOI: 10.5530/ijpcs.2019.8.3

Copyright: ๑ the author(s),publisher and licensee International Journal of Pharmacology and Clinical Sciences. This is an open-access article distributed under the terms of the Creative Commons Attribution Non-Commercial License, which permits unrestricted noncommercial use, distribution, and reproduction in any medium, provided the original work is properly cited.

This is an open access article distributed under the terms of the Creative Commons Attribution-NonCommercial-ShareAlike 4.0 License

\section{Access this article online}

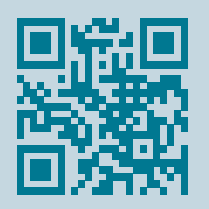

www.ijpcs.net

\section{INTRODUCTION}

The Clinical pharmacokinetics services (CPK) and Therapeutic drug monitoring (TDM) is expanding services hospital over the past several in Saudi Arabia. ${ }^{[1,2]}$ Clinical pharmacists play an essential role in the improvement of the clinical outcome of the patient and reduce the economic burden on the healthcare system in the Kingdom of Saudi Arabia (KSA). ${ }^{[3-5]}$ Several publications have described the privilege of prescribing medications and monitoring the use of medications by a clinical pharmacist on a daily basis..$^{[1,2,6-7]}$ Most of the 
current recent literature shows survey data regarding the general pharmacy practices in hospitals. ${ }^{[1,8]}$ However, in this study, we aimed to perform in-depth research on the pharmacokinetics practice at $\mathrm{MOH}$ hospital. Therefore, the objective of this study was to conduct national survey of pharmacokinetics practice with an emphasis on prescribing and dispensing stage of drug therapy and management at the Ministry of Health hospital in Saudi Arabia.

\section{METHODS}

This is a 2-month cross-sectional national survey of pharmacokinetics services with a focus on prescribing medication and dispensing at $\mathrm{MOH}$ hospitals in Saudi Arabia. This study consists of two parts: the first part captures demographic information and the second part is a questionnaire with 43 questions divided into three domains that are derived from the guidelines of the American Society of Health-System Pharmacists (ASHP) and from the literature. ${ }^{[2,8-10]}$ The domains were related to pharmacy management and resources, medication prescribing and dispensing, drug monitoring and pharmacy education and perceptions and barrier of services implementations. We used the 5 -point Likert response scale system to obtain the responses of the participants; there were close-ended questions. An electronic questionnaire was distributed to coordinators of all the clinical pharmacy services or drug information centers at $\mathrm{MOH}$ hospitals. The data were collected through the Survey Monkey system.

\section{RESULTS}

A total of 43 hospital pharmacies responded to the survey; the response rate was found to be $86 \%$. Most of the hospitals responded were with 200-299 beds (14 (32.6\%)) and with 100-199 beds (10 (23.3\%)). Most of the hospitals had accreditation from the Central Board for Accreditation of Healthcare Institutions (CBAHI) (17 (39.53\%)) and from the Joint Commotion USA (11 (25.59\%)); however, 8 (16.6\%) hospitals did not have any accreditations (Table 1). The highest level of education of the responders was found to be Bachelor of Pharmacy (22 (51.2\%)), Master of Science (12 (27.91\%)) and Doctor of Pharmacy (11 (25.58\%)). Most of the responders were with greater than or equal to 6 and 1-3 years of experience in the field of pharmacokinetics services (9 (20.9\%)). None of the responders had Board of Pharmaceutical Specialties (Table 2). The pharmacists and nurses had privileges of prescribing medication as per pharmacokinetics services at nearly

\begin{tabular}{|l|c|c|}
\hline \multicolumn{3}{|c|}{ Table 1: Demographic hospital information. } \\
\hline $\begin{array}{l}\text { Number of beds at your } \\
\text { hospital }\end{array}$ & $\begin{array}{l}\text { Response } \\
\text { Count }\end{array}$ & $\begin{array}{c}\text { Response } \\
\text { Percent }\end{array}$ \\
\hline$<50$ & 3 & $7.0 \%$ \\
\hline $50-99$ & 6 & $14.0 \%$ \\
\hline $100-199$ & 10 & $23.3 \%$ \\
\hline $200-299$ & 14 & $32.6 \%$ \\
\hline $300-399$ & 6 & $14.0 \%$ \\
\hline $400-499$ & 4 & $9.3 \%$ \\
\hline $500-599$ & 0 & $0.0 \%$ \\
\hline$=$ or >600 & 0 & $0.0 \%$ \\
\hline Medical City & 3 & $7.0 \%$ \\
\hline Answered question & 43 & \\
\hline Skipped question & 0 & \\
\hline The hospital accreditation & Response Count & R e s p o $\mathrm{n} \mathrm{s}$ Percent \\
\hline CIBAHI & 17 & $39.53 \%$ \\
\hline Joint Commotion USA & 11 & $25.58 \%$ \\
\hline Canada & 0 & $0.00 \%$ \\
\hline Saudi commission of health accreditation & 7 & $16.28 \%$ \\
\hline Non & 8 & $18.60 \%$ \\
\hline Answered question & 43 & \\
\hline Skipped question & 0 & \\
\hline
\end{tabular}

$18(46.15 \%)$ and $16(41.03 \%)$ hospitals, respectively. At 14 (37.84\%) hospitals, the pharmacists have the privilege to request an estimation of patient's drug level and at $12(30.77 \%)$ hospitals, they have the privilege to change the drug sampling time. At 15 (38.46\%) hospitals, the nurses have the privilege to request an estimation of drug level and at $12(31.58 \%)$ hospitals, they have the privilege to change drug sampling time (Table 3 ). The commonly prescribed medications via pharmacokinetic consultation were gentamicin (23 (71.88\%)), phenytoin $(23(71.88 \%))$, carbamazepine (22 $(70.97 \%))$, sodium valproate $(22(70.97 \%))$ and warfarin $(22(70.97 \%))$ (Table 4$)$. The pharmacokinetics altering system during an electronic prescription was found in $9(26.5 \%)$ hospital pharmacies, whereas in $8(23.5 \%)$ hospital pharmacies, the pharmacist participated in pharmacokinetics research (Table 5).

\section{DISCUSSION}

According to our results, the response rate was found to be good in different geographical areas of KSA. In KSA, we found a significant impact of the pharmacist on the pharmacokinetics services; therapeutic drug monitoring pharmacist had a significant impact on the patient condition and outcome. ${ }^{[4]}$ The results of our study demonstrate that the prescribing privileges of pharmacokinetics services for pharmacists and nurses in $\mathrm{MOH}$ hospitals varied. However, Pedersen et al. 
Alomi and Elshenawy.: Pharmacokinetics Services in Saudi Arabia: Prescribing and Dispensing Medication

\begin{tabular}{|c|c|c|}
\hline Academic Qualification (s): & Response Count & Response Percent \\
\hline Diploma. Pharmacy & 4 & $9.30 \%$ \\
\hline Bsc. Pharmacy & 22 & $51.16 \%$ \\
\hline Master of Science & 12 & $27.91 \%$ \\
\hline Doctor of Pharmacy & 11 & $25.58 \%$ \\
\hline Two years Residency (R1) & 1 & $2.33 \%$ \\
\hline Three years Residency (R2) & 0 & $0.00 \%$ \\
\hline Ph. D & 1 & $2.33 \%$ \\
\hline M.B.A. & 1 & $2.33 \%$ \\
\hline Answered question & 43 & \\
\hline Skipped question & 0 & \\
\hline Board of Pharmaceutical Specialty & Response Count & Response Percent \\
\hline Board Certified Ambulatory Care Pharmacist (BCACP) & 0 & $0.0 \%$ \\
\hline Board Certified Critical Care Pharmacist (BCCCP) & 0 & $0.0 \%$ \\
\hline Board Certified Nuclear Pharmacist (BCNP) & 0 & $0.0 \%$ \\
\hline Board Certified Nutrition Support Pharmacist (BCNSP) & 0 & $0.0 \%$ \\
\hline Board Certified Oncology Pharmacist (BCOP) & 0 & $0.0 \%$ \\
\hline Board Certified Pediatric Pharmacy Specialist (BCPPS) & 0 & $0.0 \%$ \\
\hline Board Certified Pharmacotherapy Specialists (BCPS) & 0 & $0.0 \%$ \\
\hline Board Certified Psychiatric Pharmacist (BCPP) & 0 & $0.0 \%$ \\
\hline Non & 38 & $100.0 \%$ \\
\hline Other (please specify) & 0 & $0.0 \%$ \\
\hline Answered question & 38 & \\
\hline Skipped question & 5 & \\
\hline Total years of Experiences in Pharmacokinetic services & Response Count & Response Percent \\
\hline$<1$ year & 4 & $9.3 \%$ \\
\hline $1-3$ years. & 9 & $20.9 \%$ \\
\hline 4-6 years. & 7 & $16.3 \%$ \\
\hline$=$ or $>6$ years. & 9 & $20.9 \%$ \\
\hline No experiences & 11 & $25.6 \%$ \\
\hline Other (please specify) & 3 & $7.0 \%$ \\
\hline Answered question & 43 & \\
\hline Skipped question & 0 & \\
\hline
\end{tabular}

\begin{tabular}{|c|c|c|c|c|c|c|c|}
\hline Answer Options & $\begin{array}{l}\text { Independent } \\
\text { Prescribing }\end{array}$ & $\begin{array}{l}\text { Refill } \\
\text { Prescribing }\end{array}$ & $\begin{array}{l}\text { Prescribing } \\
\text { under } \\
\text { physician } \\
\text { supervision }\end{array}$ & Not at all & $\begin{array}{l}\text { No of } \\
\text { existed }\end{array}$ & $\begin{array}{l}\text { Percent of } \\
\text { excited }\end{array}$ & $\begin{array}{l}\text { Response } \\
\text { Count }\end{array}$ \\
\hline For Pharmacists Medications & 10 & 3 & 12 & 21 & 18 & $46.15 \%$ & 39 \\
\hline Requesting of Drug levels & 7 & 2 & 9 & 23 & 14 & $37.84 \%$ & 37 \\
\hline Requesting of Sampling times & 7 & 3 & 6 & 27 & 12 & $30.77 \%$ & 39 \\
\hline For Nurses Medications & 8 & 4 & 10 & 23 & 16 & $41.03 \%$ & 39 \\
\hline Requesting of Drug levels & 6 & 4 & 10 & 24 & 15 & $38.46 \%$ & 39 \\
\hline Requesting of Sampling times & 6 & 4 & 7 & 26 & 12 & $31.58 \%$ & 38 \\
\hline \multicolumn{7}{|l|}{ answered question } & 39 \\
\hline \multicolumn{7}{|l|}{ skipped question } & 4 \\
\hline
\end{tabular}


Alomi and Elshenawy.: Pharmacokinetics Services in Saudi Arabia: Prescribing and Dispensing Medication

\begin{tabular}{|c|c|c|c|c|c|c|c|c|}
\hline $\begin{array}{l}\text { Answer } \\
\text { Options }\end{array}$ & $\begin{array}{l}76-100 \% \\
\text { of patients }\end{array}$ & $\begin{array}{l}51-75 \% \text { of } \\
\text { patients }\end{array}$ & $\begin{array}{l}25-50 \% \text { of } \\
\text { patients }\end{array}$ & $\begin{array}{l}<25 \% \text { of } \\
\text { patients }\end{array}$ & $\begin{array}{l}\text { We do not } \\
\text { have it }\end{array}$ & $\begin{array}{l}\text { No of } \\
\text { existed }\end{array}$ & $\begin{array}{l}\text { Percent } \\
\text { of excited }\end{array}$ & $\begin{array}{l}\text { Response } \\
\text { Count }\end{array}$ \\
\hline Gentamicin & 7 & 6 & 5 & 5 & 9 & 23 & $71.88 \%$ & 32 \\
\hline Tobramycin & 2 & 5 & 2 & 1 & 19 & 10 & $34.48 \%$ & 29 \\
\hline Amikacin & 6 & 8 & 2 & 5 & 11 & 21 & $65.63 \%$ & 32 \\
\hline Vancomycin & 10 & 8 & 1 & 4 & 10 & 23 & $69.70 \%$ & 33 \\
\hline Theophylline & 3 & 5 & 3 & 6 & 12 & 17 & $58.62 \%$ & 29 \\
\hline Digoxin & 9 & 5 & 3 & 5 & 10 & 22 & $68.75 \%$ & 32 \\
\hline Phenytoin & 7 & 7 & 3 & 6 & 9 & 23 & $71.88 \%$ & 32 \\
\hline Carbamazabine & 6 & 7 & 4 & 5 & 9 & 22 & $70.97 \%$ & 31 \\
\hline Sodium Valproate & 5 & 8 & 5 & 4 & 9 & 22 & $70.97 \%$ & 31 \\
\hline Lithium & 4 & 4 & 3 & 3 & 16 & 14 & $46.67 \%$ & 30 \\
\hline Heparin & 9 & 6 & 0 & 3 & 11 & 18 & $62.07 \%$ & 29 \\
\hline Warfarin & 12 & 5 & 0 & 5 & 9 & 22 & $70.97 \%$ & 31 \\
\hline Cyclosporine & 4 & 2 & 4 & 6 & 12 & 16 & $57.14 \%$ & 28 \\
\hline Methotrexate & 4 & 6 & 1 & 5 & 12 & 16 & $57.14 \%$ & 28 \\
\hline Tacrolimus & 2 & 3 & 3 & 6 & 14 & 14 & $50.00 \%$ & 28 \\
\hline Everolimus & 2 & 2 & 4 & 1 & 19 & 9 & $32.14 \%$ & 28 \\
\hline \multicolumn{8}{|l|}{ answered question } & 34 \\
\hline \multicolumn{8}{|l|}{ skipped question } & 9 \\
\hline
\end{tabular}

Table 5: The availability of drug-pharmacokinetics alerting system (e.g., checking allergy, drug levels (trough and peak), maximum dose, pregnancy and lactation, pharmacokinetics calculation and drug compatibility) with computerized physician order entry (CPOE).

\begin{tabular}{|c|c|c|c|c|c|c|c|c|c|c|}
\hline \multirow[b]{2}{*}{$\begin{array}{l}\text { Answer } \\
\text { Options }\end{array}$} & \multicolumn{8}{|c|}{ No. of Hospital Beds: } & \multirow[b]{2}{*}{$\begin{array}{l}\text { Response } \\
\text { Percent }\end{array}$} & \multirow[b]{2}{*}{$\begin{array}{l}\text { Response } \\
\text { Count }\end{array}$} \\
\hline & $<50$ & $50-99$ & $100-199$ & $200-299$ & $300-399$ & $400-599$ & $\begin{array}{l}=\text { or }> \\
600\end{array}$ & $\begin{array}{l}\text { Medical } \\
\text { City }\end{array}$ & & \\
\hline Yes & 0 & 0 & 4 & 3 & 2 & 0 & 0 & 0 & $26.5 \%$ & 9 \\
\hline No & 2 & 5 & 2 & 8 & 2 & 2 & 0 & 0 & $61.8 \%$ & 21 \\
\hline I do not know & 0 & 1 & 0 & 1 & 0 & 2 & 0 & 0 & $11.8 \%$ & 4 \\
\hline \multicolumn{10}{|c|}{ answered question } & 34 \\
\hline \multicolumn{10}{|c|}{ skipped question } & 9 \\
\hline
\end{tabular}

The pharmacy participating in drug-pharmacokinetics research? Pharmacist performs drug-pharmacokinetics research either as principal investigator or co-investigator ,pharmacist is likely to be (co-) author of a published paper. While drug-pharmacokinetics research shall develop mechanisms, in the form of policies and procedures, for the approval, protocols, planning and simple protocols.

\begin{tabular}{|l|l|l|l|l|l|l|l|l|l|l|}
\hline Yes & 0 & 0 & 2 & 4 & 1 & 1 & 0 & 0 & $23.5 \%$ & 8 \\
\hline No & 3 & 6 & 4 & 8 & 2 & 3 & 0 & 0 & $76.5 \%$ & 26 \\
\hline \\
answered question \\
skipped question
\end{tabular}

reported in 2017 a contradictory results, which might be the country of research had well-established TDM services. ${ }^{[11]}$ Most of the requests for the estimation of drug level and change in sampling time were prescribed by the supervising physician. This finding is slightly more than what has been reported by Alsultan et al. who conducted a national survey of pharmacy practice. This difference in results might be related to the time of conducting these studies. ${ }^{[1]}$ However, our results were found to be lower than what has been reported by Pedersen et al. in 2016, which is related to the pharmacokinetics services founded in the study country more than 60 years ago. ${ }^{[8]}$ European hospital pharmacies deliver a variety of patient-oriented clinical activities, including the provision of drug information, pharmacokinetic consultations, TDM and 
management and prevention of adverse drug reactions and medication errors. Pharmacists' involvement in managing all these activities has a great outcome in maximizing patient safety. ${ }^{[12]}$ The commonly prescribed medication during pharmacokinetics consultation was gentamicin, which is an antibiotic belonging to the class of drugs known as aminoglycosides. In the National Survey of Extended-Interval Aminoglycoside Dosing, ${ }^{[12]}$ some of the respondents may not be monitoring "true troughs" but instead may be monitoring random serum aminoglycoside concentrations delayed in the dosing interval. Moreover, there are approximately $5 \%$ of the hospitals that do not monitor serum aminoglycoside concentrations. The effect of clinical pharmacokinetics consultation service on the use of gentamicin studied at a university hospital is promising. ${ }^{[14]}$ The finding that gentamicin is the most common medication monitored through pharmacokinetics services has also been reported Ab Rahman et al. in 2013, who conducted a similar study in Malaysia, but their results showed lower frequency than that of ours. This difference might be because Ab Rahman et al. study is related to the TDM services that was established and developed prior to the $\mathrm{MOH}$ hospitals. ${ }^{[15]}$ The rate of pharmacokinetics altering system during an electronic prescription was found to be low at hospital pharmacies. This shows that hospital pharmacies have the potential need to initiate the electronic pharmacokinetic altering system among $\mathrm{MOH}$ hospitals. ${ }^{[12]}$ A competent pharmacokinetics researcher must have both pharmacokinetic calculations and TDM and dispensing skills. To enhance their knowledge on these skills, they were given more opportunities to perform pharmacokinetic calculations and TDM on essential medications in the context of enhancing patient-related outcomes. It is crucial to all pharmacists to learn according to the Accreditation Council for Pharmacy Education (ACPE) Standards and the ASHP accreditation guidelines for Postgraduate Year One PGY-1 and PGY-2 residency programs. They suggest pharmacokinetic skills are an expected area of competency in the workforce for pharmacists. In addition, the pharmacy students are expected to perform both pharmacokinetic calculations as well as TDM more frequently. ${ }^{[16-18]}$

\section{CONCLUSION}

Healthcare providers including pharmacists and nurses had a significant role in providing pharmacokinetics services. Expanding these services with standard guidelines and electronic method of prescribing medication is needed to prevent drug-related problems, improve clinical outcome of the patient and reduce economic burden.

\section{ACKNOWLEDGMENT}

None.

\section{CONFLICT OF INTEREST}

None.

\section{ABBREVIATIONS}

KSA: Kingdom of Saudi Arabia; MOH: Ministry of Health; PK: Clinical Pharmacokinetic; CPS: Clinical pharmacokinetics services; ASHP: American Society of Health-System Pharmacists; TDM: Therapeutic drug monitoring.

\section{ORCID ID}

Yousef Ahmed Alomi (D) https://orcid.org/0000-0003$1381-628 \mathrm{X}$

\section{REFERENCES}

1. Alsultan MS, Mayet AY, Khurshid F, Al-jedai AH. Hospital pharmacy practice in Saudi Arabia: Drug monitoring and patient education in the Riyadh region. Saudi Pharm J. 2013;21(4):361-70.

2. Alomi YA, Alghamdi SJ, Alattyh RA, Alshahrani AM, Shorog EM, Alasmary SA, et al. National survey of pharmacy practice at MOH hospitals 2016: Drug monitoring and patient education. Value Heal. 2017;A36-A36.

3. Alomi YA, Almudaiheem HY. Clinical outcomes of pharmacokinetics services managed by pharmacist at Ministry hospital in Saudi Arabia. Value Heal. 2017;20(5):A38-A38.

4. Alomi YA, Almudaiheem HY. Clinical and Economic Outcomes of Pharmacist Intervention during Therapeutic Drug Monitoring Program in Saudi Arabia. Value Heal. 2016;19(7):A465-6.

5. Alomi YA, Almudaiheem HY. Clinical outcomes of Vancomycin therapeutic monitoring services at Ministry of Health hospital in Saudi Arabia. Value Heal. 2017;20(5):A42-A42.

6. Law MR, Fisher J, Sketris IS. Independent pharmacist prescribing in Canada. Can Pharm J. 2012;145(1):17-23.

7. Baqir W, Miller D, Richardson G. A brief history of pharmacist prescribing in the UK European Journal of Hospital Pharmacy. Science and Practice. 2012;19:487-8.

8. Pedersen CA, Schneider PJ, Scheckelhoff DJ. ASHP national survey of Pharmacy Practice in Hospital settings: Monitoring and patient education-2015. Am J Health Syst Pharm. 2016;73(17):1307-30.

9. Howard CE, Capers CC, Bess DT, Anderson RJ. Pharmacokinetics services in Department of Veterans affairs medical centers. Am J Hosp Pharm. 1994;51(13):1672-5.

10. Ab Rahman AF, Ahmed Abdelrahim HE, Mohamed IMI. A survey of therapeutic drug monitoring services in Malaysia. Saudi Pharm J. 2013;21(1):19-24.

11. Pedersen CA, Schneider PJ, Scheckelhoff DJ. ASHP national survey of pharmacy practice in hospital settings: Prescribing and transcribing-2016. Am J Health Syst Pharm. 2017;74(17):1336-52.

12. Frontini R, Miharija-Gala T, Sykora J. EAHP survey 2010 on hospital 
Alomi and Elshenawy.: Pharmacokinetics Services in Saudi Arabia: Prescribing and Dispensing Medication

pharmacy in Europe: Parts 4 and 5. Clinical services and patient safety. Eur J Hosp Pharm. 2013;20(2):69-73.

13. Chuck SK, Raber SR, Rodvold KA, Areff D. National Survey of ExtendedInterval Aminoglycoside Dosing. Clin Infect Dis. 2000;30(3):433-9.

14. Nor EL din A, Al-Khamis K, Bawazir S, et al. Effect of Clinical Pharmacokinetics Consultation Service On the use of Gentamicin level at a university hospital. Bull Fac Pharm Cairo Univ. 1998;36(1):81-4.

15. Ab Rahman AF, Ahmed AHE, Mohamed IMI. A survey of therapeutic drug monitoring services in Malaysia. Saudi Pharm J. 2013;21(1):19-24.
16. American Society of Health-System Pharmacist. ASHP Accreditation standard for postgraduate year one (PGY1). 2012;1-23. Available from: http://www.ashp.org/DocLibrary/Accreditation/ASD-PGY1-Standard.aspx

17. American Society of Health-System Pharmacist. ASHP Accreditation standard for postgraduate year Two (PGY2). 2017;1-23. Available from: http://www.ashp.org/DocLibrary/Accreditation/ASD-PGY1-Standard.aspx

18. Dornblaser EK. A needs assessment of pharmacokinetic skills performed on advanced pharmacy practice experiences by student pharmacists. Curr Pharm Teach Learn. 2017;9(1):95-100.

Cite this article as: Alomi YA, Elshenawy RA. National Survey of the Pharmacokinetics Services at the Ministry of Health Hospitals in Saudi Arabia: Prescribing and Dispensing Medication. Int J Pharmacol. Clin. Sci. 2019;8(1):11-6. 